\title{
Liquidity Management and Profitability of Manufacturing Companies in Nigeria
}

\author{
${ }^{1}$ Ben-Caleb, Egbide (Ph.D Candidate), ${ }^{2}$ Olubukunola, Uwuigbe (Ph.D), \\ ${ }^{3}$ Uwuigbe, Uwalomwa (Ph.D) \\ Department of Accounting, School of Business College of Development Studies Covenant University Ota
}

\begin{abstract}
Liquidity and its management determines to a great extent the growth and profitability of a firm. This is because either inadequate liquidity or excess liquidity may be injurious to the smooth operations of the organization. This seeming controversy has attracted a lot of interest in the subject of liquidity management. The primary aim of this paper is to investigate the relationship between liquidity and profitability. The analysis is based on a sample of 30 manufacturing companies listed on the Nigeria Stock Exchange for the period 20062010. The result suggests that current ratio and liquid ratio are positively associated with profitability while cash conversion period is negatively related with profitability of manufacturing companies in Nigeria. The association in all the cases was however, statistically insignificant, indicating low degree of influence of liquidity on the profitability of manufacturing companies. Hence, the overall state of liquidity should be improved by establishing more realistic credit policy which would engender shorter cash conversion period $(C C P)$, hence have a favourable impact on the profitability of the company.
\end{abstract}

Key Words: Liquidity, Profitability, Management, Manufacturing Sector, Nigeria.

\section{Introduction}

Working capital management is among the four cardinal decision areas of financial management, for which every commercially oriented organisation has to make (Pandey, 2005). Interestingly, working capital components of a firm's financial management deals with the liquidity aspect of a firm and hence fundamental for the effective and efficient operations as well as the sustainability of its going concern status (Enyi, 2006). It is worth mentioning from the outset that working capital and liquidity are use in this paper to mean one and the same thing and relates to the management of current assets and currents liabilities of an enterprise. This synonymy is based on the observation that working capital ratios are the most common measures of liquidity (Lamberg, \& Valming, 2009). Liquidity management as it were, determine to a large extent the quantity of profit that result as well as the value of shareholders wealth (Ben-Caleb, 2008). This is because, a firm in order to survive must remain liquid as failure to meet its obligation in due time results in bad credit rating by the short term creditors, reduction in the value of goodwill in the market and may ultimately leads to liquidation (Bhavet, 2011). Hence, a good and firm financial management policy seeks to maintain adequate liquidity in order to meet its short-term maturing obligations without impairing profitability.

Unfortunately, the principal focus of most organizations is profitability maximization while the need for efficient management of liquid assets is ignored. This approach is justified by the belief that profitability and liquidity are conflicting goals. Hence, a firm can only pursue one at the expense of the other, in consonance with the theory of liquidity and profitability trade-off. On the contrary, Padachi (2006) advised that a firm is required to maintain a balance between liquidity and profitability while conducting its daily operations. This is because both inadequate liquidity and surplus liquidity directly affect profitability (Ogundipe, Idowu and Ogundipe, 2012). For instance, when the "necessary" level of liquid assets is exceeded, their surpluses when the market risk remains stable, become a source of ineffective utilisation of resources which has an adversed effect on profitability. An insufficient working capaital on the other hand, result in a liquidity crisis which is life threatening and can force a company into bankruptcy, often with little notice; this also affect the returns of the firm (Spinella, 2007)

This paper investigates the seemingly conflicting relationship between liquidiy and profitability goals of companies using evidence from Nigerian manufacturing sector. The apriori assumptuon is that there is no relationship between profitability and liquidity planning of manufacturing companies in Nigeria. The rest of the paper is orgnised into four sections namely: theoretical framework/literature review, methodology, data analyses and discusion and conclusion.

\section{Literature Review and Theoretical Framework}

Liquidity and profitability are the two main purposes of working capital management (WCM) and relates to the matching of assets and liabilities movements over time (Pass \& Pike, 1984 cited in Lamberg \& 
Valming, 2009). The general claim in literature centre around liquidity/profitability tradeoff hypothesis which posit that these two financial terms pose conflicting ends to an organisation, hence a pusuit of one will mean a trade off of the other (Dash \& Hanuman, 2008). However, the other side of thinking holds that managers can puesue both liquidity and profitability goals as these two objective have a direct relationship. These two viewed were observed by Chakraborty (2008) when evaluating the relationship between working capital and profitability of Indian pharmaceutical companies. He pointed out that there were two distinct schools of thought on this Issue: first that working capital is not a factor of improving profitabity and there may be a negative rlationship between them. Secondly, that investment in working capital plays a vital role to improve corporate profitability, and unless there is a minimum level of investment of working capital, output and sales cannot be maintained. These two directions in literature are briefly reviewed.

First, a number of studies had supported the liquidity/profitability trade-off theory. These include; Shin \&Seonen (1998); Deloof (2003); Eljelly (2004); (Garcia-Teruel\& Martinez-Salano, 2004); Lazaridiss\&Tryfonidis (2005); Nobanee and AlHajjar (2005); Akella (2006), Reheman\& Nasr (2007); Sadlovska, \&Viswanathan, (2007); Uyar (2009); Garcia-Teruel and Martinez-Solano (2007); Dash and Hanuman (2008); Raheman and Nasr (2007); Mathuva (2009); Samiloglu and Demirgunes (2008); Falope \& Ajilore (2009); Ashokkumar and Manohar (2010); Bhunia and Brahma (2011). In these works, significantly nagative association bewtween liquidity management and profitability were the results.

Specifically, Shin \&Seonen (1998) studied a sample of 58,985 listed companies in America for a period of twenty years and found a strong negative relationship between the net trade cycle (cash conversion cycle) and corporate profitability. On the basis of this finding, they concluded that managers can increase the value for their shareholders by reducing the cash conversion period to a reasonable minimum. In the same vein, Deloof (2003) also reached the same conclusion when he investigated this relationship on a sample of 1009 large Belgian non-financial firms. Garcia-Teruel\& Martinez-Salano, (2004) investigated the effect of WCM on profitability using a sample of 8872 small and medium size Spanish firms and found that a shorter Cash Conversion Cycle can improve the firm's profitability. A similar study was carried out in Athens by Lazaridiss\&Tryfonidis (2005) studying a sample of 131 listed firms for the period 2001-2004. They found a strong negative relationship between profitability and CCC and advised that managers handle correctly the cash conversion cycle and keep each of its components at optimal level in order to enhance profitability.

Furthermore, Nobanee and AlHajjar (2005) investigated the relationship between working capital management and profitability of a sample of 2123 Japanese non-financial firms listed in the Tokyo Stock Exchange for a period of 15 years (1990-2004). They found that managers can increase profitability of their firms by shortening the cash conversion cycle, the receivable collection period and the inventory conversion period as well as lenghtening the payable deferral period. They however warn that in lengthening the CPP care should be taken to avoid damaging the firm's reputation which can significantly harm its profitability in the lung run. The study of indian and pakistani firms carried out by Alkella, (2006) and Reheman\& Nasr (2007) respectively arrived at similar results, which are strong negative link between liquidity or working capital and profitability. In this regard, Sadlovska, \&Viswanathan, (2007) opined that the best performing companies have their liquidity (Cash Conversion Cycle) about 5-6 times shorter than the average and low performing once. Dash and Hanuman (2008) adopted a goal programming model to study the trade off between liquidity and profitabilty and found that working capiatl and inventaory in particular, should be streamlined to enhance profitability. Again, Uyar (2009) found a significant negative correlation between CCC and firm size as well as with profitability among Turkey firms using ANOVA and perason moment correlation. Similar findings where that of Mathuva (2009) studying this relationship among 30 firms in Nairobi..

In Nigeria, Ben-Caleb (2009) studied the relationship between the components of working capital and profitability measured by Return on assets using a sample of 25 non-fiancial firms for 2005 and 2006 period and found out that only debtors collection period has a significant negative association with profitability. Similarly, Falope \& Ajilore (2009) also reported a strong negative correlation between working capital and profitability among Nigerian firm..

More recent studies has also confirm the existence of the tarde off between liquidity and profitability trade off. For instance Ashokkumar and Manohar (2010) did a case study of Cement Industry in Tamilnadu and found significant negative relation between the firm's profitability and its liquidity level. Also, Bhunia and Brahma (2011) studied the importance of liquidity management on profitability and found a significant negative relationship between the profitability measured by ROCE and all the independent variables (CR, LR, ALR, DER, AOI, AOD, and AOC) except for CR which indicated a positive influence on profitability.An explaination to some of these results could be gleaned from the KPMG (2005) who asserted that a shortening the CCC releases liquidity and impacts directly on the company's financial position as well as the company's returns.

Inversely, some study's findings had tended to render the profitability-liquidity trade off invalid. In other words, that there exist a direct and positive relationship between a longer liquidity and profitability. For 
instance,Shin \&Soenen, 1998 argued that a firm can have larger sales with a generous credit policy, which extends the cash cycle. In this case, the longer cash conversion cycle may result in higher profitability. Also, Deloof, (2003) assert that, A longer cash conversion cycle might increase profitability because it leads to higher sales. The above arguments are in tandem with the findings of Lyroudi\&Lazaridis (2000) who studied this relationship among the food industry in Greek and found a positive and significant relationship between the CCC and profitability (measured by ROI and NPM). This result indicates that a longer cash conversion cycle can improve company's profits.

Samiloglu and Demirgunes (2008) investigated this relationship among Istanbul firms and found that growth in sales affects firm profitability positively. This result invariably surport the view that liquidity and profitability are directly associated since liquidity is enhance by sale's growth. Singh and Pandy (2008) suggested that, for the successful working of any business orgasation, fixed and current assets play a vital role, and that the management of working capital is essential as it has a direct impact on profitability and liquidity. Lamberg and Valming, (2009) studied the impact of liquidity management on profitability during financial crises with a sample of companies listed on stockholm stock Exchange's small and mid capitalist with some restrictions. Adopting a quantitative methodology and regression analysis, they find out that the adaptation of liquidity strategies do not have a significant impact on profitability measured by ROA. However, that increased use of liquidity forcasting and short-term financing during the financial crisis had a positive impact on ROA. In other word frquent monitoring and forcasting on liquidity levels and makiing more short-term investments can provide gains in profitability.

Bunia and Khan (2011) studied liquidity management efficiency of Indian steel companies with a sample of 230 campanies for 9 years period (2002-2010) and found a petite associattion between the indicators of liquidity and profitability (ROCE). Bunia, Khan and Mukhuti (2011) also found that working capital in terms of liquidity is accountable for poor capacity, under-utilisation and poor consumption and that there exist a high positive relationship between liquidity and profitability.Gill A, Biger N and Mathur (2010) found a positive relationship between cash conversion cycle and profitability amongs firms in the United States. Other studies with positive and insignificance association between liquidity and profitability include Khan, Akash, Hamid and Hussain, (2011) who investigated the existence of Risk-Return Trade off Hypothesis using empirical evidence from Textile Sector of Pakistan and concluded that there exist a moderate risk-return trade off in between profitability and liquidity hypothesis. Also, Sur \& Chakraborty (2011) found an insignificant relationship between these two variable in India; In the oil and gas sector, Saleem Q. \&Rehman R.U. (2011) found a less than significant effect of liquidity ratios (current ratios, quick ratios and liquid ratio) on Return on equity.

Khan Z. Jawaid S.T, Arif I. and Khan M. N.(2011) conducted a disaggregated analysis of the relationship between working capiatal and profitability of pakistani firms and found. Regression results indicate that average collection period has insignificant effects on profitability except in sugar and allied sector. At the same time debit ratio also has insignificant effect on profitability except in engineering sector. Furthermore average payment period has insignificant effect only in sugar and allied sector. Inventory turnover, current ratio and firm size has significant effects on profitability in all sectors. Sensitivity analysis confirms that the results are robust. Pandey and Jaiswal (2011) examine the interrelationship between profitability and liquidity using NALCO as a case study and found that the different working capital ratios have statistically insignificant impact on the ROCE of the company.Afeef M.(2011) analyzing the Impact of Working Capital Management on the Profitability of SME's in Pakistan, found that the indicators of working capital management which were Receivable Collection Period, Inventory Conversion Period, Payable Deferral Period,Cash Conversion Cycle, had a perceptible impact on profitability measured by return on assets of firms under study.

It would be observed that, while literature are awash with stduies relating to liquidity/working capital in relationship wth profitability, there exist scanty studies in Nigeria that address this issues. Even the few studies available, did not consider a comprehensive profitability measure like return on capiatl emloyed (ROCE) which this study utilised.

\section{Methodology of the Study}

This study adopts a quantitative methodology in view of the nature of the variables used for analyses. A sample of 30 manufacturing companies listed on the Nigeria stock exchange was purposively selected. Data were extracted from the annual financial statements of the sampled companies for the 2006-2010 making a total of 150 firm year observations. Both discriptive statistic and a multiple regression analyses were applied for data analyses.

The choice of variable used in this study was influence by previouse studies. The dependent variable in the study is corporate profitability which is measured here by the Return on Capital Employed (ROCE) and define as: 
ROCE $=\frac{\text { PBIT }}{\text { Capital Employed }} * 100$

For the independent variables, the paper adopts the view of Eljelly (2004) who opined that the cash conversion cycle (CCC) is a very importance measure of liquidity. So CCC is taken as the main independent variable to test its impact on ROCE. Other traditional liquidity variables namely: current ratio (CR) and quick ratio (QR) are also included as independent variables. The natural Logarithm of sales and the natural logarithm of total assets are used here as control variables.

\subsection{Model Specification}

To enable the examination of the relationship between Liquidity management and corporate profitability, the paper specify the following definitional model;

$R O C E=F(C C C, C R, L R, L n S, L n T A)$

The above equation when expressed in explicit econometric form gives

ROCEit $=\beta_{0}+\beta_{1}$ CCCit $+\beta_{2}$ CRit $+\beta_{3}$ LRit $+\beta_{4}$ LnSit $+\beta_{6}$ LnTAit $+\varepsilon$-----------ii

Where; ROCE $E_{\mathrm{it}}$ : Return on capital employed of organization $\mathrm{i}$ at time $\mathrm{t} ; \mathrm{i}=1,2, \ldots, 30$ Organizations, CCC: Cash conversion period, CR: Current Ratio, LR: Liquid Ratio, LnS: Natural Logaraithm of Sales, LnTA: Natural Logarithm of Total Assets, $\beta_{0}$ : The intercept of equation, $\beta \mathrm{i}:$ : Coefficients of $\mathrm{X}$ it variables, $t:$ Time $=$ $1,2, \ldots \ldots, 5$ years., $\varepsilon$ : The errorS term

The expectation in this paper a priori is that cash conversion period (CCP), the current ratio (CR) and the quick ratio $(\mathrm{QR})$ would bear significant inverse relationship with return on capital employed (ROCE). This is in consonance with the liquidity profitability theory which is the theoretical foundation of this study. For the control variables; the natural logarithm of sales and the natural logarithm of total assets, it is expected that they will bear significant positive relationship with ROCE. This because profit is a portion of sales. Therefor it is natural that the higher the sales the higher the profit. Also, it is assets that is used to generate profit. So, if the assets are managed efficiently it will have a direct relationship with profitability.

\subsection{Descriptive Analysis}

\section{Data Analyses and Discussion of Result}

The discriptive statistic presented in table 4.2.1 shows the mean, range, minimum, maximum and standard deviation of all the variables under consideration. The table indicate that manufacturing companies in Nigeria generates a mean return on capiatl employed (ROCE) of about $23 \%$ with a negative minimum of $216 \%$ and an abnormal maximum of $145 \%$.

Table 4.1 Descriptive Statistics

\begin{tabular}{|l|r|r|r|r|r|r|r|}
\hline & \multicolumn{1}{|c|}{$\mathrm{N}$} & \multicolumn{1}{c|}{ Minimum } & \multicolumn{1}{c|}{ Maximum } & \multicolumn{1}{c|}{ Mean } & \multicolumn{1}{c|}{$\begin{array}{c}\text { Std. } \\
\text { Deviation }\end{array}$} & \multicolumn{2}{|c|}{ Kurtosis } \\
\cline { 2 - 8 } & \multicolumn{1}{|c|}{ Statistic } & \multicolumn{1}{c|}{ Statistic } & \multicolumn{1}{c|}{ Statistic } & \multicolumn{1}{c|}{ Statistic } & \multicolumn{1}{c|}{ Statistic } & \multicolumn{1}{c|}{ Statistic } & Std. Error \\
\hline ROCE & 150 & -216.3300 & 145.2800 & 22.571000 & 56.452424 & 7.325 & .394 \\
& 150 & .1360 & 3.4108 & 1.403667 & .5922609 & 1.068 & .394 \\
LR & 150 & .0994 & 2.5029 & .822924 & .4676994 & 1.636 & .394 \\
CCP & 150 & -2218 & 817 & 35.28 & 268.614 & 36.317 & .394 \\
LnSL & 150 & 18.1900 & 25.9500 & 22.756333 & 1.7973423 & -.742 & .394 \\
LnTA & 150 & 19.5900 & 25.5000 & 22.703933 & 1.6239061 & -1.174 & .394 \\
Valid N & 150 & & & & & & \\
(listwise) & & & & & & \\
\hline
\end{tabular}

Source: Computed output (SPSS, 2012)

The table also reveal that the mean values of current ratio (1.4) and liquid ratio (0.8) are below the standard conventional rule of 2:1 and 1:1 respectively. These indicates that on the average, manufacturing companies in Nigeria may find it difficult to meet their short term maturing obligations. However, with the maximum of 3.41 and 2.50 for the CR and LR respectively show that some of the companies are doing very well liquidity wise, as they are not likely to encounter any difficulty in meeting their short term obligations. Other attributes revealed by the table with respect to the variables under consideration are that it takes an average of 35 days for the companies to convert their stock into cash. However, the minimum and maximum CCC indicates that, while some companies collect cash in advance, other companies takes over two years to convert inventory to cash. This gives a clue of the poor perfornance of manufacturing companies in nigeria. 
Correlation Analysis.

Correlation analysis was used to determined the strength and direction of the linear relationship between the variables under consideration. This is shown the correlation matrix in table

Table 4.2 Correlation Matrix

\begin{tabular}{|c|c|c|c|c|c|c|c|}
\hline \multirow{3}{*}{$\begin{array}{l}\text { ROC } \\
\mathrm{E}\end{array}$} & \multirow{3}{*}{$\begin{array}{l}\text { Pearson } \\
\text { Correlation } \\
\text { Sig. (2-tailed) }\end{array}$} & \multirow{2}{*}{$\begin{array}{r}\text { ROCE } \\
1\end{array}$} & \multirow{2}{*}{$\frac{\mathrm{CR}}{.289(* *)}$} & \multirow{2}{*}{$\frac{\mathrm{LR}}{.300(* *)}$} & $\mathrm{CCP}$ & LnSL & LnTA \\
\hline & & & & & .086 & $.350(* *)$ & $.318(* *)$ \\
\hline & & & .000 & .000 & .293 & .000 & .000 \\
\hline & $\mathrm{N}$ & 150 & 150 & 150 & 150 & 150 & 150 \\
\hline CR & Pearson & $.289(* *)$ & 1 & $.845(* *)$ & $.429(* *)$ & .018 & -.009 \\
\hline & Sig. (2-tailed) & .000 & & .000 & .000 & .822 & .916 \\
\hline & $\mathrm{N}$ & 150 & 150 & 150 & 150 & 150 & 150 \\
\hline LR & $\begin{array}{l}\text { Pearson } \\
\text { Correlation }\end{array}$ & $.300(* *)$ & $.845(* *)$ & 1 & $.242(* *)$ & -.047 & -.019 \\
\hline & Sig. (2-tailed) & .000 & .000 & & .003 & .565 & .817 \\
\hline & $\mathrm{N}$ & 150 & 150 & 150 & 150 & 150 & 150 \\
\hline СCP & $\begin{array}{l}\text { Pearson } \\
\text { Correlation }\end{array}$ & .086 & $.429(* *)$ & $.242(* *)$ & 1 & .122 & .042 \\
\hline & Sig. (2-tailed) & .293 & .000 & .003 & & 137 & .613 \\
\hline & $\mathrm{N}$ & 150 & 150 & 150 & 150 & 150 & 150 \\
\hline LnSL & $\begin{array}{l}\text { Pearson } \\
\text { Correlation }\end{array}$ & $.350(* *)$ & .018 & -.047 & .122 & 1 & $.948(* *)$ \\
\hline & Sig. (2-tailed) & .000 & .822 & .565 & .137 & & .000 \\
\hline & $\mathrm{N}$ & 150 & 150 & 150 & 150 & 150 & 150 \\
\hline $\begin{array}{l}\text { LnT } \\
\text { A }\end{array}$ & $\begin{array}{l}\text { Pearson } \\
\text { Correlation }\end{array}$ & $.318(* *)$ & -.009 & -.019 & .042 & $.948(* *)$ & 1 \\
\hline & Sig. (2-tailed) & .000 & .916 & .817 & .613 & .000 & \\
\hline & $\mathrm{N}$ & 150 & 150 & 150 & 150 & 150 & 150 \\
\hline
\end{tabular}

** Correlation is significant at the 0.01 level (2-tailed).

\section{Source: Output from SPSS 15.0}

Table 4.2, shows the result of the correlation computation. The result indicate that all the predictor vartiables namely: current ratio (CR), liquid ratio (LR), cash conversion period (CCP), natural logarithm of sales (LnS) and natural logarithm of total assets (LnTA) are positively related with profitability measured by return on capital employed (ROCE). Specifically, the result shows that CR and LR have a positive and significant association with ROCE. This is in fact a contravention of our theoretical foundation (liquidity- profitability trade off theory) which posits that profitability and liquidity are inversely related or that there must always be a trade-off between profitability and liquidity. It is however consistent with the findings of Bhunia, Khan \& Mukhuti (2011), and Pandey \& Jaiswal (2011). The relationship between CCP and ROCE is also positive but insignificant as exemplified in the P-value of 0.293. The implication being that ROCE and CCP are directly related. In other words, the longer the CCP, the better the ROCE and vice versa. The likely factor that could account for this kind scenario is the liberal policy of most suppliers in Nigeria. For instance, on an average, the creditors payment period is 163 days which is higher than the debtors collection period of 71days and inventory conversion period of 131days. This liberal policy adopted would result in higher sales for the companies thereby leading to higher overall profitability of the companies. The result consistent with the view of Padachi (2006) whose research showed CCP and profitability to be positively correlated. This positive relation for CCP is consistent with the view that resources are blocked at the different stage of the supply chain, thus prolonging the operating cycle. This might increase profits due to increase sales, especially where the costs of tied up capital is lower than the benefits of holding more inventories and granting more trade credit to customers. Also the small manufacturing firms may be able to obtain trade credit from the suppliers.

Also, the relationship between out control variables ( $\mathrm{LnS}$ and LnTA) and the ROCE is positive and significant. This is expected since higher sales is expected to engender higher profit and the assets are the pivot for on which profit is generated. 
Fig 4.1 -Scatterplot of the Relationship between Return on capital employed and Cash conversion period.

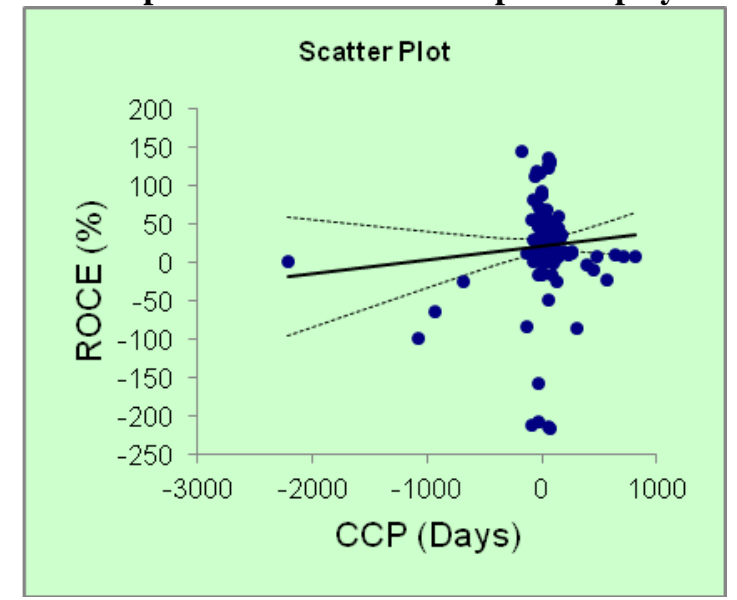

\section{Source: Computed output of StatistiXL package (2013)}

Since the major trust of this paper is to investigate the relationship between liquidity and profitability. It was neccerary to probe the revelation of the zero order correlation further by using partial correlation. Partial correlation helps us to explore the relationship between two variables of interest while controlling for other confounding variables.

The result of the partial correlation coefficient shown on table 4.5 revealed significant changes the correlation coeffients of the variables under consideration. For CR LR and LnSL the partial correlation indicated significant changes in the strength of the relationships from 0.289 (CR), 0.300 (LR) and 0.350 (LnSL) to $0.036,0.160$ and 0.199 respectively. The direction of these relationships were not affected as they still remain positive. But for CCP and LnTA both the strenth and directions of therelationship were significantly altered in the partialcorrelation. For instance the relationship between CCP and ROCE change from 0.086 to -0.073 . the implication of this result is that is the influence of the other independent variables is controlled, CCP will bear a negative relationship with ROCE, even though it is not signifiant.

\subsubsection{Regression Analysis}

To further investigate the predictive ability of our predictor variables on the creterion variable we employed the multiple regression analysis. The analysis was guided by the simple difinitional model specified in section three. we recall the model for emphases:

ROCEit $=\beta_{0}+\beta_{1}$ CCCit $+\beta_{2}$ CRit $+\beta_{3}$ LRit $+\beta_{4}$ LnSit $+\beta_{6}$ LnTAit $+\varepsilon$

The regression result is shown in table 3,4 and 5 . Table 3 is the model summary. The adjusted R Square value of 0.205 indicate that about $20.5 \%$ of the variation in ROCE is explained by the independent variables included in our model.

Table 3

Model Summary(b)

\begin{tabular}{|l|l|r|r|r|r|}
\hline Model & R & R Square & $\begin{array}{c}\text { Adjusted R } \\
\text { Square }\end{array}$ & $\begin{array}{c}\text { Std. Error of } \\
\text { the Estimate }\end{array}$ & Durbin-Watson \\
\hline 1 & $.481(\mathrm{a})$ & .232 & .205 & 50.33609 & 2.060 \\
\hline
\end{tabular}

a Predictors: (Constant), LnTA, CR, CCP, LR, LnSL

b Dependent Variable: ROCE

The overall significance of the model was assessed by the values in the ANOVA table shown on table 4 . The result indicate that our model is statistically significance as exemplified in the F value of 8.682 and a P-value < 0.05

Table 4

ANOVA(b)

\begin{tabular}{|c|c|c|c|c|c|}
\hline Model & $\begin{array}{l}\text { Sum of } \\
\text { Squares }\end{array}$ & $\mathrm{df}$ & Mean Square & $\mathrm{F}$ & Sig. \\
\hline $\begin{array}{ll}1 & \text { Regression }\end{array}$ & $\begin{array}{r}109988.64 \\
5\end{array}$ & 5 & 21997.729 & 8.682 & $.000(a)$ \\
\hline
\end{tabular}




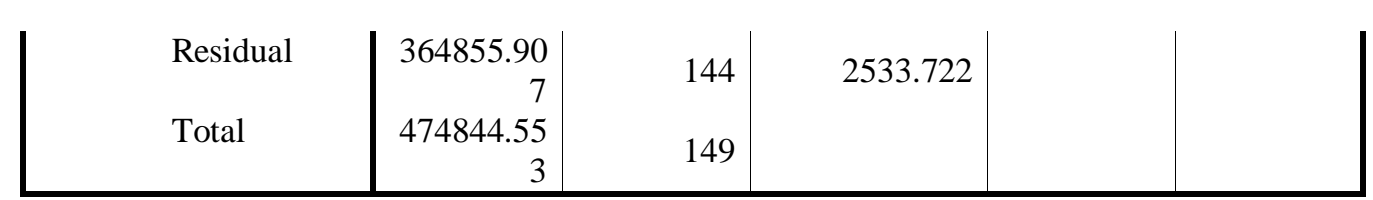

a Predictors: (Constant), LnTA, CR, CCP, LR, LnSL

b Dependent Variable: ROCE

The Standardised Beta Coefficients of the variables shown in table 5 indicates that all the predictor variables makes contribution to the variation in the creterion variable, albeit, at varying degrees of significance. For instance, sales makes the highest contribution to the prediction of the ROCE with a B-coefficient of 0.601 , while CR makes the least contribution with a coefficient of 0.067. Also, the T statistic and the Sig-values indicates that only Sales (LnSL) and Liquid Ratioand (LR) generate significant impact on ROCE at $5 \%$ and $10 \%$ levels respectively. The impact of the other predictor variables namely; CR, CCP and LnTA are not significant even at $10 \%$ levels.

Table 5 : Regression Coeffients

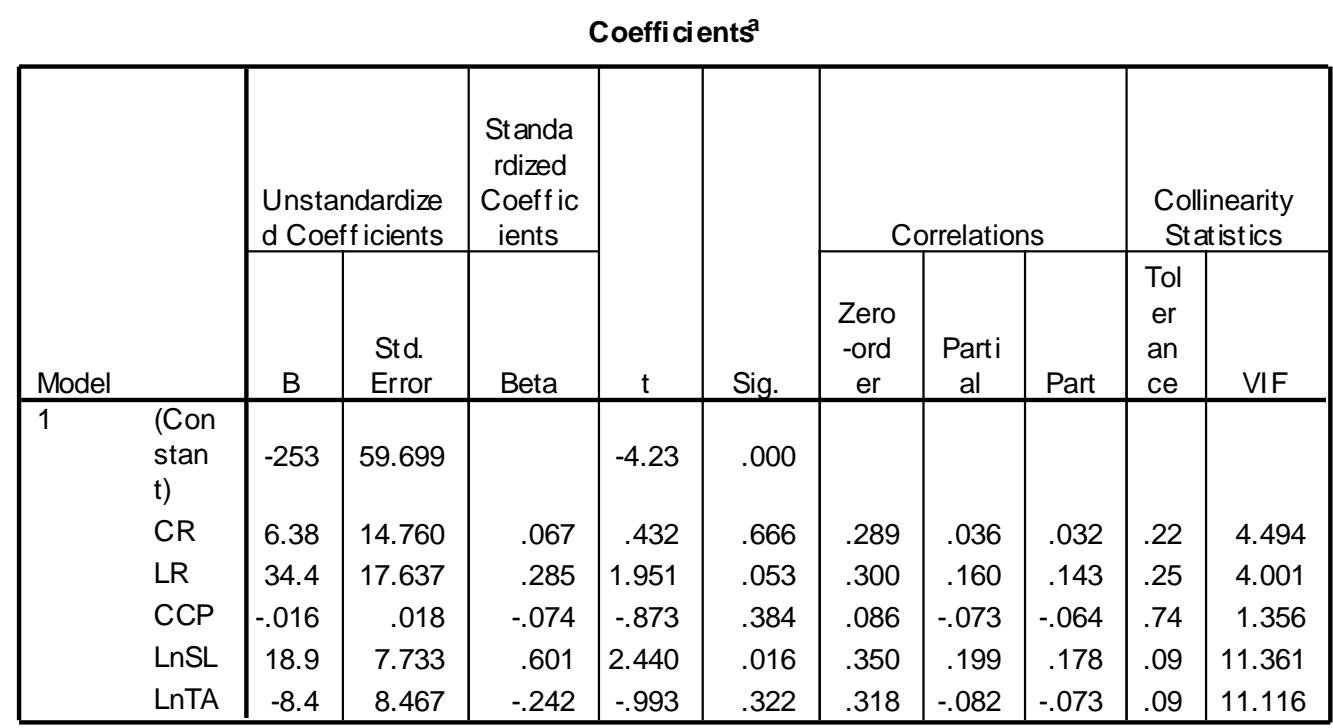

a. Dependent Variable: ROCE

\section{Hyothesis Testing}

The assumption of this paper from the outset was that there is no relationship between profitability and liquidity planning of manufacturing companies in Nigeria. The zero order correlation coefficients indicates that current ratio (CR) and Liquid ratio (LR) are positively and significantly related to profitability measured by ROCE. The relationship between cash conversion cycle and ROCE indicate positive but insignificant relationship. However, the partial correlation revealed contrary, as the significanness of the CR and LR were lost although the direction remian the same. For CCP, the partial corelation coeffient indicate that CCP is insignificantly negatively related to ROCE. In view of the superiority of partial correlation over zero order correlation in a multivariate analysis, this paper relied on the result of the partial correlation for judgement. Also, the regression analysis coroborated the result of the partial correlation in terms of direction (table 5). The regression result indcates that non of the three liquidity ratios tested namely, CR, LR and CCP has a significant impact onprofitability measured by ROCE at $99 \%$ oreven $95 \%$ significance level.

If we match partial correlation and the regression analysis, is only safe to retain our apriori proposition or that liquidity does not have significant degree of association with profitability in Nigeria.

\section{Conclusion}

The cardinality of liquidity management in any organisation cannot be over emphasised. This is because either inadequate liquidity or excess liquidity may be injurious to the smooth operations of the organization. This paper was set out to explore the seemingly controversial profitability/liquidity trade off theory. From literature, the controversy as regard the relationship and impact of liquidity on profitability is yet to be resolve as divergent finding exist. Our empirical investigation using both the partial correlation and regression analysis reveal that liquidity ratios measure by current ratio (CR), Liquid ratio (LR) and Cash 
conversion period (CCP) have a petite relationship with profitability measured by return on capital employed (ROCE). It also revealed that CR and LR are positively associated with ROCE, while CCP is negatively associated with ROCE.

Although, these result is not in tandem with our a-priori expectation and the theoretical bases of this study, except for CCP in terms of direction, it is however consistent some literature especially those of Singh and Pandy (2008); Bunia and Khan (2011); Lamberg and Valming (2009); Khan, Hamid and Hussain (2011); Sur \&Chakraborty (2011) etc. who all found insignificant relationship and impact between liquidity and profitability at different environments.

The implication of the above is that liquidity has low degree of influence on the profitability of manufacturing companies in Nigeria. This is to be expected given the present moribund state of many manufacturing companies in Nigeria. This only goes to confirm inefficiency and ineptitude in the management of liquid assets. Hence, there is a lost in the contribution expected from efficient liquidity planning. It is worthy to mention here that the negative direction reveals with respect to CCP and ROCE is very informative of the fact that the cash conversion cycle needs to be shortened to engender increase in profitability.

From the forgoing, it is the candid recommendation of this paper that overall state of liquidity should be improved so as to have a favourable impact on the profitability of the company and also, the establishment of a more realistic credit policy which would lead to gap minimization of cash flows as well as the reduction of cash conversion period which has the potential to improve a profitability. It is also sugested that further research be conducted on the same topic with different sector and extending the years of the sample

\section{References}

[1]. Afeef M.(2011) “Analyzing the Impact of Working Capital Management on the Profitability of SME's in Pakistan” International Journal of Business and Social Science

[2]. Akella, S. (2006). Working Capital Management in India. In Gopala K.M.G.(2006) (ed). Toward Better working Capital Management. Punjagutta, the Icfai University press

[3]. Ben-Caleb, E. (2009). Working Capital Management and Profitability of Listed Companies in Nigeria: Nigeria Research Journal of Accountancy; Vol 1 (1) PP 44-57

[4]. Bhavet (2011) Management of liquidity- A case study of Tisco Ltd. International Journal of Research in IT \& Management 149 IJRIM Volume 1, Issue 2 (ISSN 2231-4334)

[5]. Bhunia A. (2011) Liquidity management efficiency of Indian Steel Companies (a Case Study) Far East Journal of Psychology and Business Vol 3 No 3.

[6]. Bhunia, A. and Brahma, S.B. (2011). Importance of Liquidity Management on Profitability Asian Journal of Business Management. Volume3 no.2 pp 108-117

[7]. Bhunia, A. and Khan, I.U. (2011). Liquidity Management Efficiency of Indian Steal Companies: A Case Study. Far East Journal of Psychology and Business: Volume 3 Number 3 pp 3-13

[8]. Bhunia, A., Khan, I and Mukhuti, S, (2011). A Study of Managing Liquidity. Journal of Management Research; volume 3 No.3. Retrieved from www.macrothink.org/jmr

[9]. Dash, M. and Hanuman R. (2008). A Liquidity-Profitability Trade-Off Model for Working Capital Management. Retrieved from http://ssrn.com/abstract=1408722

[10]. Deloof, M. (2003). Does Working Capital Management Affect Profitability of Belgian Firms? Journal of Business Finance and Accounting, 30(3) \& (4). Retrieved 15/03/08 from http://papers.ssrn.com/sol3/papers.cfm?abstract_id=415364

[11]. Eljelly A. (2004). Liquidity-profitability tradeoff: an empirical investigation in an emerging market. International Journal of Commerce and Management.

[12]. Enyi, P.E. (2006) Applying Relative Solvency to Working Capital Management: the Break Even Approach. In Gopala K.M.G.(2006) (ed). Toward Better working Capital Management. Punjagutta, the Icfai University press

[13]. Falope O.I, Ajilore O.T. (2009). Working capital management and corporate profitability: evidence from panel data analysis of selected quoted companies in Nigeria. Research Journal of Business Management.

[14]. Garcia-Teruel P.J and Martinez-Solano PM, (2007). Effects of working capital management on SME profitability. International Journal of Managerial Finance.

[15]. Gill A, Biger N. \& Mathur N. (2010) The Relationship Between Working Capital Management And Profitability: Evidence From The United States. Business and Economics Journal, Volume 2010: BEJ-10

[16]. Greiner, Larry E. (1998) Evolution and Revolution as Organizations Grow.Harvard Business Review.

[17]. Khan M. I, Akash R. Hamid K. and Hussain F.(2011) Working Capital Management and Risk-Return Trade off Hypothesis: (Empirical Evidence from Textile Sector of Pakistan)European Journal of Economics, Finance and Administrative Sciences ISSN 1450-2275 Issue 40.

[18]. KPMG, (2005). Working Capital management survey: How European Companies Manage their Working Capital. KPMG International. Retrieved on 15/03/08 from http://www.ch/library/pdf/kpmg_survey_working_capital_management_e.pdf

[19]. Khan Z. Jawaid S.T, Arif I. and Khan M. N.(2011) Working capital management and firm's profitability in Pakistan: A disaggregated analysis Business Graduate, IQRA University Karachi-75300, Pakistan.

[20]. Lamberg, S. \& Valming, S. (2009). Impact of Liquidity Management of Profitability: A Study of the Adaptation of Liquidity Strategies in a Financial Crisis. Umea. Umea School of Business

[21]. Lazaridis, J. and D.Tryfonidis, (2006), Relationship between Working Capital Management and Profitability of listed companies in the Athens Stock Exchange, 19 Journal of Financial Management and Analysis.

[22]. Mathuva D. (2009) The influence of working capital management components on corporate profitability: a survey on Kenyan listed firms. Research Journal of Business Management.

[23]. Nobanee, H. and AlHajjar, M. (2005). A Note on Working Capital Management and Corporate Profitability of Japanese Firms. Retrieved from http://ssrn.com/abstract=1433243

[24]. Ogundipe, E.O., Idowu, A, and Ogundipe, L.O (2012). Working Capital Management, Firm's Performance and Market Valuation in Nigeria. International Journal of Social and Human Sciences. Volume 6 pp 143-147 
[25]. Padachi K. (2006) Trends in Working Capital Management and its Impact on Firms'Performance: An Analysis of Mauritian Small Manufacturing Firms.International Review of Business Research Papers Vo. 2 No. 2.

[26]. Pallant J. (2004). SPSS Survival Manual- A step by step guide to data analysis using SPSS. Open University press. McGraw-Hill House

[27]. Pandey, I.M. (2005). Financial Management ( $9^{\text {th }}$ edition).New Delhi; Vikas Publishing House PVT LTD.

[28]. Pandey S. and Jaiswal V.K. (2011) Effectiveness on Profitability: Working Capital Management SCMS Journal of Indian Management.

[29]. Raheman A. and Nasr M. (2007)Working Capital Management And Profitability - Case Of Pakistani Firms International Review of Business Research PapersVol.3 No.1.

[30]. Saleem Q. \&Rehman R.U. (2011) Impacts of liquidity ratios on profitability (Case of oil and gas companies of Pakistan)Interdisciplinary Journal of Research in Business Vol. 1, Issue. 7.

[31]. Samiloglu F.and Demirgunes K. (2008). The Effect of Working Capital Management on Firm Profitability: Evidence from Turkey.The International Journal of Applied Economics and Finance.

[32]. SurD. \& Chakraborty K. (2011) Evaluating Relationship of Working Capital and Profitability: A Study of Select Multinational Companies in the Indian Pharmaceutical Sector.The IUP Journal of Management Research, Vol. X, No. 2

[33]. Uyar, A. (2009). The Relationship of Cash Conversion Cycle with Firm Size and Profitability: An Empirical Investigation in Turkey. International Research Journal of Finance and Economics. Issue 24 pp 186-193 